$p$-ISSN 1693-9484, $e$-ISSN : 2621-8313

Majalah Ilmiah Bahari Jogja (MIBJ)

Vol. 18 No. 1, Februari 2020 (37-56)

DOI : $10.33489 /$ mibj.v18i1.227

(C) 2020 Sekolah Tinggi Maritim Yogyakarta

\title{
Analisis Kualitas Pelayanan Transportasi Laut (Survei pada Perusahaan Pelayaran di Pelabuhan Tanjung Priok, 2015)
}

\author{
Sumardi $1^{*}$ \\ ${ }^{1}$ Sekolah Tinggi Maritim Yogyakarta, Jl. Magelang KM 4.4, Yogyakarta 55284, \\ Indonesia \\ * Corresponding Author. E-mail : sumardistimaryo@ gmail.com. Telp : 081284744445
}

\begin{abstract}
Abstrak
Penelitian ini bertujuan untuk menganalisis kualitas pelayanan transportasi laut Pelabuhan Tanjung Priok, Jakarta. Penelitian menggunakan metode SERVQUAL untuk mengukur kualitas pelayanan yang diterima pelanggan berdasarkan model kualitas pelayanan (gap model). SERVQUAL bertujuan untuk mengukur lima dimensi kualitas pelayanan yaitu: bukti fisik, keandalan, daya tanggap, jaminan, dan empati yang didasarkan pada analisis kesenjangan (gap analysis) antara harapan dan kinerja pelayanan. Penelitian menggunakan instrumen berupa kuesioner dengan melibatkan 91 perusahaan pelayaran yang diambil dengan teknik acak sederhana. Data penelitian selanjutnya dianalisis dengan analisis Servqual. Hasil penelitian menunjukkan bahwa secara umum kinerja pelayanan Pelabuhan Tanjung Priok dinilai perusahaan pelayaran cukup baik dan tingkat harapan pelayanan tergolong tinggi. Dimensi pelayanan yang dianggap paling penting adalah keandalan, bukti fisik, daya tanggap, jaminan dan empati. Untuk meningkatkan kualitas pelayanan terhadap perusahaan pelayaran, maka perlu melakukan perbaikan pelayanan dengan urutan prioritas: bukti fisik, keandalan, daya tanggap, jaminan, dan empati. Upaya perbaikan juga perlu mengacu pada hasil diagram kartesius, yaitu dengan berusaha mempertahankan atribut-atribut pelayanan pada kuadran B, meningkatkan perbaikan atribut pelayanan kuadran A, dan mengurangi upayaupaya yang dilakukan terhadap atribut pelayanan pada kuadran C. selain itu, perlu juga dilakukan penelitian lebih lanjut tentang kualitas pelayanan dengan menggunakan dimensi kualitas pelayanan lain, seperti 7S dari McKinsey yang dianalisis dengan menggunakan pendekatan kualitatif.
\end{abstract}

Kata Kunci: Kualitas Pelayanan, Transportasi Laut

\begin{abstract}
This research aimed to analyzed ofservice quality os sea transportation on shipping company at The Port of Tanjung Priok, Jakarta. This research used SERVQUAL method. The purpose of SERVQUAL is to measure the five dimensions of service quality, that is: tangible, reliability, responsiveness, assurance, and empathy and based on gap analysis between expectation and service performance. This research using instrument in questionnaire form with involved 91 shipping company taken by simple random sampling technique. The research data analyzed Servqual. The result of this research show that in
\end{abstract}


generally the service performance at at The Port of Tanjung Priok Jakarta perceived shipping companies is good enough and the level of expectation is high. The service dimension that perceived most important by shipping companies is reliability, followed by tangible, responsiveness, assurance and empathy. To improving service quality for shipping companies, then need to do the service improvement with priority order start from tangible, reliability, responsiveness, assurance, and empathy. The improvement effort also need refer to cartesius diagram, that is with trying to defense the service attributes in $B$ quadrant, enhanced service attributes in A quadrant, and minimize the effort that doing on service attributes in $C$ quadrant. Beside that, need to do the next research about service quality with using another service quality dimensions, such as $7 S$ from McKinsey that analyzed by using qualitative approach.

Keywords: Service Quality, Sea Transportation

\section{PENDAHULUAN}

Masalah pelayanan sangat penting, populer dan sekaligus vital sejalan dengan perkembangan kebutuhan, harapan dan keinginan manusia dalam bidang jasa. Kini masyarakat tidak menyukai pelayanan yang berbelit-belit, lama, tidak akurat, minim atensi dan kering empati. Mereka menginginkan pelayanan yang cepat tetapi sekaligus tepat dan penuh empati. Dengan kata lain, masyarakat menghendaki keinginan, harapan dan kebutuhannya dapat dipenuhi dalam waktu singkat dan memuaskan.

Kecenderungan tersebut tentu saja perlu direspon sigap oleh siapa pun yang memiliki aktivitas pelayanan, terutama yang ingin aktivitasnya survive dan memiliki citra positif. Untuk itu, otoritas organisasi yang bergerak dalam bidang jasa (pelayanan) perlu mengevaluasi secara terus menerus dan berkesinambungan: apakah pelayanan yang diberikan selama ini sudah sesuai dengan keinginankeinginan masyarakat; atau justru sebaliknya masih terdapat kesenjangan (gap) antara pelayanan yang diberikan dengan pelayanan yang diharapkan oleh masyarakat. Terjadinya kesenjangan mengindikasikan adanya kualitas pelayanan yang belum prima, sehingga berpeluang menurunkan kinerja organisai secara keseluruhan.

Upaya mewujudkan kinerja pelayanan yang prima membutuhkan kualitas sumber daya manusia yang ungggul dan dukungan sarana dan prasarana yang memadai. Terkait dengan urgensi itu, Zeithaml, Parasuraman dan Berry (1990: 235) mengemukakan pentingnya lima dimensi pelayanan yang perlu diperhatikan, yaitu: reliability, assurance, tangibles, empathy dan responsiveness. Reliability merupakan kemampuan untuk memberikan pelayanan yang telah dijanjikan secara handal dan akurat. Assurance meliputi pengetahuan dan kesopanan karyawan atau pegawai dalam melayani pelanggan serta kemampuan mereka untuk menjaga kepercayaan pelanggan. Tangibles mencakup penampilan fasilitas fisik, peralatan, tenaga kerja dan alat komunikasi. Emphaty yaitu kepedulian, perhatian individual yang disediakan oleh perusahaan kepada pelanggan. Responsiveness yaitu kemauan untuk membantu pelanggan dan menyediakan layanan dengan segera. 
Kelima dimensi pelayanan tersebut penting bagi setiap organisasi yang memiliki aktivitas pelayanan. Di kalangan perusahaan-perusahaan swasta yang bergerak dalam bidang jasa, dimensi-dimensi pelayanan itu bukan hal baru. Perusahaan jasa pada umumnya menyadari betul arti penting dimensi-dimensi pelayanan itu bagi aktivitas organisasinya. Bagi perusahaan jasa, pelayanan merupakan pilar penting bagi keberlangsungan bisnisnya. Kesadaran itulah yang mendorong mereka berupaya memberikan pelayanan terbaik kepada pelanggannya. Namun, di pihak lain, bagi sebagian besar instansi-instansi pemerintah yang memberikan pelayanan publik, termasuk perusahaan milik pemerintah yang bergerak dalam bidang pelayanan transportasi laut, hal itu belum memperoleh porsi yang wajar. Pelayanan umumnya kurang mendapat perhatian serius, antara lain ditandai oleh proses pelayanan yang cenderung berbelit-belit, memakan waktu lama, kering empati, bahkan sering tidak akurat. Kondisi ini pada akhirnya menuai kritik dan keluhan dari masyarakat pengguna layanan.

Kecenderungan seperti itu juga terjadi pada Pelabuhan Tanjung Priok, sebuah perusahaan milik pemerintah yang bergerak dalam bidang pelayanan transportasi laut di kawasan Pelabuhan Tanjung Priok, Jakarta. Pelayanan kapal dan barang yang dilakukan oleh Pelabuhan Tanjung Priok sering dikeluhan oleh perusahaan-perusahaan pelayaran. Pelayanan yang diberikan kurang cepat sehingga mengganggu aktivitas transportasi yang dilakukan perusahaan. Selain itu, pelayanan yang diberikan juga sering kurang simpatik.

Transportasi laut menuntut berbagai pelayanan yang berkualitas baik untuk kapal, muatan dan juga penumpangnya. Pelayanan transportasi laut sesuai Undang-Undang Republik Indonesia Nomor 25 Tahun 2009 tentang Pelayanan Publik, termasuk dalam pelayanan publik. Pasal 1 menyatakan bahwa pelayanan publik adalah kegiatan atau rangkaian kegiatan dalam rangka pemenuhan kebutuhan pelayanan sesuai ketentuan perundang-undangan bagi setiap warga negara atau penduduk atas barang, jasa dan atau pelayanan administratif yang diberikan oleh penyelanggara pelayanan publik. Dengan peraturan perundangundangan tersebut diharapkan masyarakat transportasi laut mendapatkan perlindungan dan kepastian hukum, terwujudnya sistem pelayanan yang baik dan penyelenggaraan pelayanan yang sesuai dengan peraturan perundang-undangan yang berlaku. Namun sesuai yang telah diuraikan di atas belum dapat dipenuhi.

Berdasarkan latar belakang masalah di atas, dapat diidentifikasi sejumlah masalah yang potensial mempengaruhi kualitas pelayanan transportasi laut di antaranya: 1) kinerja pelayanan transportasi laut Pelabuhan Tanjung Priok masih kurang memuaskan, 2) kepentingan perusahaan-perusahaan pelayaran atas pelayanan transportasi laut Pelabuhan Tanjung Priok belum terpenuhi, 3) terjadinya kesenjangan antara kinerja pelayanan kapal yang diberikan pelabuhan Tanjung Priok dengan harapan perusahaan-perusahaan pelayaran, 4) kompensasi pegawai kurang menjamin pegawai untuk pelayanan transportasi laut secara optimal, 5) kebijakan pimpinan pelabuhan kurang mendukung pelayanan transportasi laut yang optimal, 6) sarana dan prasarana pelabuhan kurang menunjang pelayanan transportasi laut, dan 7) biaya operasional kurang memadai untuk menunjang pelayanan transportasi laut. 
Dalam artikel ini pembahasan dibatasi pada kinerja pelayanan transportasi laut Pelabuhan Tanjung Priok, harapan perusahaan pelayaran atas pelayanan transportasi laut Pelabuhan Tanjung Priok, tingkat kepentingan perusahaan pelayaran atas pelayanan transportasi laut Pelabuhan Tanjung Priok, dan kesenjangan antara kinerja pelayanan transportasi laut pelabuhan dengan harapan perusahaan pelayaran atas pelayanan transportasi laut Pelabuhan Tanjung Priok.

\section{KAJIAN LITERATUR}

\section{Konsep Pelayanan}

Pelayanan merupakan terjemahan dari istillah service dalam bahasa Inggris, yang menurut Kotler (dalam Tjiptono, 2004: 6) berarti "setiap tindakan atau perbuatan yang dapat ditawarkan oleh satu pihak ke pihak yang lain, yang pada dasarnya bersifat intangible (tidak berwujud fisik) dan tidak menghasilkan kepemilikan sesuatu." Bagi Zeithaml, et al. (2002, dalam Kandampully, 2011: 101), pelayanan merupakan semua isyarat dan pertemuan yang terjadi sebelum, selama, dan setelah transaksi. Sedangkan Kotler dan Armstrong (dalam Kartajaya, 2009: 7) menjelaskan bahwa "service is any activity or benefit that one party can offer to another which is essentially intangible and does not result in ownership of anything." Artinya, pelayanan adalah aktivitas atau manfaat yang ditawarkan oleh satu kelompok ke kelompok lainnya berupa sesuatu yang bersifat tidak berwujud dan bukan merupakan hasil dari pemiulikan atas sesuatu.

Pengertian pelayanan juga diungkapkan oleh Hill (dalam Winkler, 2009: 31) sebagai perubahan kondisi seseorang, atau suatu barang milik beberapa unit ekonomi, yang disebabkan sebagai akibat dari aktivitas beberapa unit ekonomi lainnya. Kartajaya (2009: 2) juga mengemukakan bahwa layanan merupakan salah satu proses penting dalam meningkatkan value perusahaan bagi pelanggan sehingga banyak perusahaan menjadikan budaya layanan sebagai standar sikap orang di dalam perusahaan. Lebih jauh dikatakan bahwa budaya layanan yang dilakukan secara terintergrasi akan menciptakan nilai-nilai layanan, yang akan mempengaruhi tingkat pengulangan pelanggan dalam membeli produk. Oleh karena itu, nilai layanan yang tercipta harus selalu dikelola terus-menerus, tidak hanya saat melakukan pendekatan kepada pelanggan dan saat transaksi, tetapi juga setelah terjadi transaksi.

Menurut Majid (2011: 35), pelayanan sangat berhubungan dengan upaya atau tindakan untuk memenuhi kebutuhan orang atau organisasi. Kata kuncinya adalah upaya/tindakan, hubungan antar manusia ada komunikasi dan kebutuhan (ada sesuatu yang ditawarkan). Layanan juga merupakan setiap kegiatan atau manfaat yang ditawarkan suatu pihak kepada pihak lain yang pada dasarnya tidak berwujud dan tidak mengakibatkan kepemilikan apapun (Simamora, 2001: 172).

Gronroos (dalam Ratminto dan Winarsih, 2005: 2) menyatakan bahwa pelayanan adalah suatu aktivitas atau serangkaian aktivitas yang bersifat tidak kasat mata yang terjadi sebagai akibat adanya interaksi antara konsumen dengan karyawan atau hal-hal lain yang disediakan oleh perusahaan pemberi pelayanan yang dimaksud untuk memecahkan permasalahan konsumen/pelanggan. Selain itu 
pelayanan adalah proses pemenuhan kebutuhan melalui aktivitas orang lain yang langsung (Moenir, 2006: 16-17).

Kotler (2003: 265) mengungkapkan bahwa organisasi harus memperhatikan empat karakter khusus suatu pelayanan, yakni: (1) tanpa wujud (service intangibility), (2) keterikatan jasa pelayanan dan penyedia jasa tidak dapat dipisahkan (service inseparability), (3) variabilitas pelayanan (service variabiltiy), dan (4) pelayanan langsung digunakan dan habis (service perishability). Tanpa wujud berarti bahwa jasa/pelayanan tidak dapat dilihat, diraba, didengar, atau dicium sebelum jasa itu dibeli. Keterikatan pelayanan jasa dan penyedia jasa dimisalkan sebagai suatu produk fisik dihasilkan, kemudian disimpan, lalu dijual, dan akhirnya dikonsumsi. Sebaliknya pada sisi lain, jasa dijual terlebih dahulu, baru diproduksi dan dikonsumsi pada saat yang sama. Service inseparability berarti bahwa jasa pelayanan tidak dapat dipisahkan dari penyedia jasa pelayanan itu sendiri, baik penyedia jasa itu sebuah mesin atau seseorang, atau suatu kelompok orang (organisasi). Variabilitas pelayanan berarti bahwa kualitas jasa pelayanan tergantung pada siapa yang menyediakan atau menghasilkan jasa itu, juga tergantung pada kapan, di mana, dan bagaimana jasa pelayanan itu diselenggarakan. Pelayanan langsung habis berarti bahwa jasa pelayanan tidak dapat disimpan untuk kemudian dijual kembali atau digunakan.

\section{Kualitas Pelayanan}

Kualitas jasa atau pelayanan merupakan faktor utama yang mempengaruhi kepuasan pelanggan. Faktor ini penting karena tergantung pada persepsi pelanggan. Menurut Simamora (2003: 179), konsep kualitas sering dianggap sebagai ukuran relatif kebaikan suatu produk atau layanan yang terdiri atas kualitas desain dan kualitas kesesuaian. Kualitas desain merupakan fungsi spesifikasi produk, sedangkan kualitas kesesuaian adalah suatu ukuran seberapa jauh suatu produk mampu memenuhi persyaratan kualitas yang telah ditetapkan. Pada kenyataanya aspek ini bukanlah satu-satunya aspek kualitas. Simamora (2003: 179) menjelaskan dalam perspektif Total Quality Management (TQM), tidak hanya aspek hasil yang ditekankan, melainkan juga meliputi proses, lingkungan dan manusia. Hal ini tampak jelas pada definisi Goetsh dan Davis (dalam Simamora, 2003: 180) yang menyatakan bahwa kualitas merupakan suatu kondisi dinamis yang berhubungan dengan produk, layanan, manusia, proses, lingkungan yang memenuhi atau melebihi harapan.

Sejalan dengan pengertian kualitas di atas, Zethaml dan Bitner (2009: 117) mendefinikan kualitas pelayanan sebagai penyerahan atau penyampaian pelayanan secara relatif lebih unggul (excellent) atau superior terahadap harapan pelanggan (customer expectations). Zeithaml dan Bitner menekankan selain aspek hasil, yang tidak kalah pentingnya adalah proses penyampaian pelayanan tersebut kepada pelanggan.

Parasuraman, et al (dalam Shahin, 2007: 2) menyebutkan bahwa kualitas pelayanan adalah perbedaan antara pelayanan yang diharapkan dengan pelayanan yang diterima. Apabila harapan lebih besar jika dibandingkan dengan kinerja, maka kualitas yang dirasakan lebih kecil jika dibandingkan dengan kepuasannya, karenanya ketidakpuasan konsumen terjadi. 
Dalam riset selanjutnya, Parasuraman, Zeithhaml dan Berry (dalam Tjiptono dan Chandra, 2011: 198) menemukan adanya overlapping di antara beberapa dimensi di atas. Oleh sebab itu, kesepuluh dimensi tersebut disederhanakan menjadi lima dimensi pokok. Hal ini yan kemudian menjadi instrumen SERVQUAL untuk mengukur kualitas pelayanan (jasa) yang diterima pelanggan berdasarkan model kualitas pelayanan/jasa (gap model). Model ini pada intinya beranggapan bahwa gap terjadi akibat ketidaksesuaian kinerja pelayanan dengan harapan pelanggan, yang meliputi lima dimensi sebagai berikut:

a. Tangibles (bukti fisik); meliputi fasilitas fisik, perlengkapan, pegawai dan sarana komunikasi serta kendaraan operasional. Dengan demikian bukti langsung/wujud merupakan satu indikator yang paling konkrit. Wujudnya berupa segala fasilitas yang secara nyata dapat terlihat.

b. Reliability (keandalan/kepercayaan); merupakan kemampuan memberikan pelayanan yang dijanjikan dengan segera dan memuaskan. Menurut Lovelock, reliability to perform the promised service dependably, this means doing it right, over a period of time. Artinya, keandalan adalah kemampuan perusahaan untuk menampilkan pelayanan yang dijanjikan secara tepat dan konsisten. Keandalan dapat diartikan mengerjakan dengan benar sampai kurun waktu tertentu. Pemenuhan janji pelayanan yang tepat dan memuaskan meliputi ketepatan waktu dan kecakapan dalam menanggapi keluhan pelanggan serta pemberian pelayanan secara wajar dan akurat.

c. Responsiveness (daya tanggap); yaitu sikap tanggap pegawai dalam memberikan pelayanan yang dibutuhkan dan dapat menyelesaikan dengan cepat. Kecepatan pelayanan yang diberikan merupakan sikap tanggap dari petugas dalam pemberian pelayanan yang dibutuhkan. Sikap tanggap ini merupakan suatu akibat akal dan pikiran yang ditunjukkan pada pelanggan.

d. Assurence (jaminan); mencakup pengetahuan, kemampuan, kesopanan dan sifat dapat dipercaya yang dimiliki karyawan, bebas dari bahaya, risiko dan keragu-raguan. Jaminan adalah upaya perlindungan yang disajikan untuk masyarakat bagi warganya terhadap resiko yang apabila resiko itu terjadi akan dapat mengakibatkan gangguan dalam struktur kehidupan yang normal.

e. Emphaty (empati); meliputi kemudahan dalam melakukan hubungan, komunikasi yang baik dan memahami kebutuhan pelanggan. Empati merupakan individualized attention to customer. Empati adalah perhatian yang dilaksanakan secara pribadi atau individu terhadap pelanggan dengan menempatkan dirinya pada situasi pelanggan.

\section{Mengukur Kualitas Jasa}

Setiawan (2011: 37-42) melihat dua teori kualitas jasa yang selama ini mendominasi dalam praktek manajemen jasa, yaitu; model Nordic dan model Gap ServQual. Sebagai rujukan dalam analisis digunakan teori Model Gap ServQual. Pendekatan kualitas jasa ini banyak dijadikan acuan dalam riset pemasaran. Menurut Parasuraman dan rekan-rekannya bahwa model ServQual ini dibangun atas adanya perbandingan dua faktor utama, yaitu: (a) persepsi pelanggan atas layanan yang nyata mereka terima (perceived service) dan (b) layanan yang sesungguhnya diharapkan (expected service). Dengan kata lain, kualitas jasa dapat didefinisikan sebagai seberapa jauh perbedaan antara kenyataan dan harapan 
pelanggan atas layanan yang mereka terima. Model ServQual ini banyak digunakan oleh perusahaan untuk melakukan analisis kualitas jasa yang diberikan dan pengaruhnya terhadap tingkat kepuasan pelanggan yang direpresentasikan oleh kesenjangan (gap) antara harapan dan persepsi pelanggan. Tjiptono dan Chandra (2011: 216-220) mengatakan bahwa model yang dinamakan ServQual (singkatan dari Service Quality) ini dikembangkan dengan maksud untuk membantu para manajer dalam menganalisis sumber masalah kualitas dan memahami cara-cara memperbaiki kualitas jasa. Model ini diilustrasikan pada Gambar.

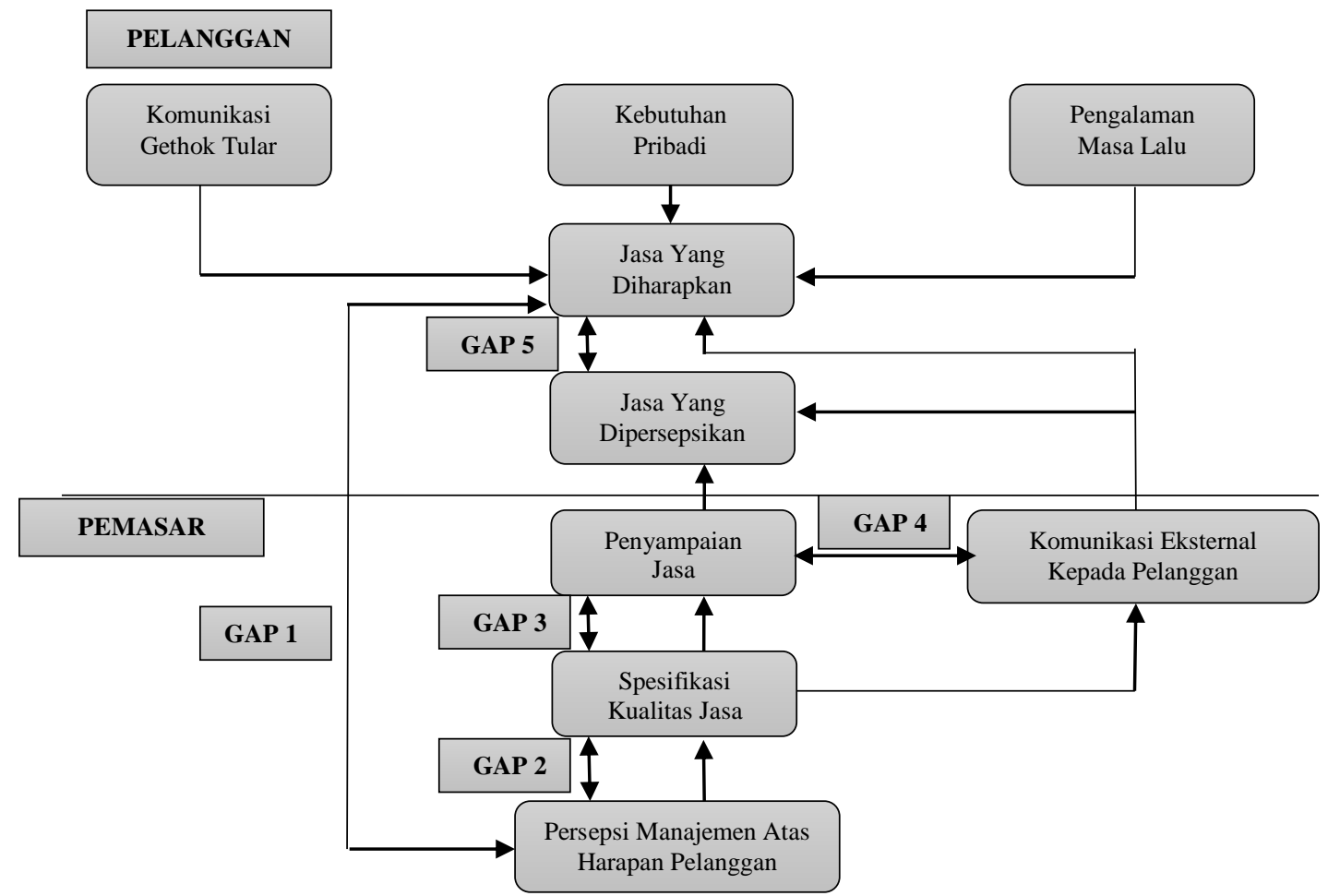

Gambar : Model Konseptual SERVQUAL

Sumber: Zeithaml et al., (1990, dalam Tjiptono dan Chandra, 2011: 216-220)

Lima gap utama yang terangkum dalam Gambar di atas meliputi:

1. Gap Antara Harapan Pelanggan dan Persepsi Manajemen (Knowledge Gap) Gap ini berarti bahwa pihak manajemen mempersepsikan ekspektasi pelanggan terhadap kualitas jasa secara tidak akurat. Beberapa kemungkinan penyebabnya antara lain: informasi yang didapatkan dari riset pasar dan analisis permintaan kurang akurat; interpretasi yang kurang akurat atas informasi mengenai ekspektasi pelanggan; tidak adanya analisis permintaan; buruknya atau tiadanya aliran informasi ke atas (upward information) dari staf kontak pelanggan ke pihak manajemen; dan terlalu banyak jenjang manajerial yang menghambat atau mengubah informasi yang disampaikan dari karyawan kontak pelanggan ke pihak manajemen.

2. Gap Antara Persepsi Manajemen terhadap Harapan Konsumen dan Spesifikasi Kualitas Jasa (Standards Gap). 
Gap ini berarti bahwa spesifikasi kualitas jasa tidak konsisten dengan persepsi manajemen terhadap ekspektasi kualitas. Penyebabnya antara lain: tidak adanya standar kinerja yang jelas; kesalahan perencanaan atau prosedur perencanaan yang tidak memadai; manajemen perencanaan yang buruk; kurangnya penetapan tujuan yang jelas dalam organisasi; kurangnya dukungan dan komitmen manajemen puncak terhadap perencanaan kualitas jasa; kekurangan sumber daya; dan situasi permintaan berlebihan.

3. Gap Antara spesifikasi Kualitas Jasa dan Penyampaian Jasa (Delivery Gap) Gap ini berarti bahwa spesifikasi kualitas tidak terpenuhi oleh kinerja dalam proses produksi dan penyampaian jasa. Sejumlah penyebabnya antara lain: spesifikasi kualitas terlalu rumit dan/atau terlalu kaku; para karyawan tidak menyepakati spesifikasi tersebut dan karenanya tidsk memenuhinya; spesifikasi tidak sejalan dengan budaya korporat yang ada; manajemen operasi jasa buruk; kurang memadainya aktivitas internal marketing; serta teknologi dan sistem yang ada tidak memfasilitasi kinerja sesuaii dengan spesifikasi. Kurangnya terlatihnya karyawan, beban kerja terlampau berlebihan, dan standar kinerja dapat dipenuhi karyawan (terlalu tinggi atau tidak realistis) juga dapat menyebabkan terjadinya gap ini. Selain itu, mungkin pula karyawan dihadapkan pada standar-standar yang kadangkala saling bertentangan satu sama lain.

4. Gap Antara Penyampaian Jasa dan Komunikasi Eksternal (Communications Gap)

Gap ini berarti bahwa janji-janji yang disampaikan melalui aktivitas komunikasi pemasaran tidak konsisten dengan jasa yang disampaikan kepada para pelanggan. Hal ini dapat disebabkan oleh beberapa factor, di antaranya: perencanaan komunikasi pemasaran tidak terintegrasi dengan operasi jasa; kurangnya koordinasi antara aktivitas pemasaran eksternal dan operasi jasa; organisasi gagal memenuhi spesifikasi yang ditetapkannya, sementara kampanya komunikasi pemasaran sesuai dengan spesifikasi tersebut; dan kecenderungan untuk melakukan "over-promise, under-deliver." Iklandan slogan/janji perusahaan seringkali mempengaruhi ekspektasi pelanggan. Jika penyedia jasa memberikan janji berlebihan, maka resikonya adalah harapan pelanggan dapat membumbung tinggi dan sulit dipenuhi.

5. Gap Antara Jasa yang Dipersepsikan dan Jasa yang Diharapkan (Service Gap) Gap ini berarti bahwa jasa yang dipersepsikan tidak konsisten dengan jasa yang diharapkan. Gap ini dapat menimbulkan sejumlah konsekuensi negatif, seperti kualitas buruk (negatively confirmed quality) dan masalah kualitas; komunikasi gethok tular yang negatif; dampak negatif terhadap citra korporat atau citra lokal; dan kehilangan pelanggan. Gap ini terjadi apabila pelanggan mengukur kinerja/prestasi perusahaan berdasarkan kriteria yang berbeda, atau dapat pula keliru dalam menginterpretasikan kualitas jasa bersangkutan.

\section{Transportasi Laut}

Terminologi "transportasi'" terdiri atas dua kata Latin, yakni trans berarti seberang dan portare berarti mengangkut. Transportasi berarti mengangkut ke seberang atau memindahkan sesuatu dari satu tempat ketempat yang lain diseberang, "sesuatu" dapat diartikan barang angkutan dan/atau orang. Jasa 
transportasi dapat diartikan sebagai kegiatan layanan mengangkut barang dan/atau penumpang dari satu tempat ke tempat yang lain (Lasse, 2014: 63).

Transportasi antara lain terjadi di laut. Sistem angkutan laut adalah jaringan pelayanan angkutan barang dan/atau penumpang dalam jumlah terbesar dengan menggunakan kapal melaui laut. Infrastruktur kunci utama transportasi laut adalah pelabuhan; alasanya adalah perjalanan kapal berawal dan berakhir dipelabuhan, dan kegiatan alih muat (cargo handling) ataupun turun-naik penumpang berlangsung di pelanuhan (Lasse, 2014: 71).

Salah satu komponen transportasi laut adalah pelabuhan. Pelabuhan dalah tempat yang terdiri atas daratan dan/atau perairan dengan batas-batas tertentu sebagai tempat kegiatan pemerintahan dan kegiatan pengusahaan yang dipergunakan sebagai tempat kapal bersandar, naik turun penumpang, dan/atau bongkar muat barang, berupa terminal dan tempat berlabuh kapal yang dilengkapi dengan fasilitas keselamatan dan keamanan pelayaran dan kegiatan penunjang pelabuhan serta sebagai tempat perpindahan intra dan antarmoda transportasi" (Lasse, 2014: 3). Menurut Fair (dalam Lasse, 2014: 3), pelabuhan diartikan sebagai tempat dimana tersedia fasilitas untuk menurunkan dan/atau menaikkan penumpang, dan kegiataan bonkar-muat barang dari kendaraan air ke kendaraan darat dan sebaliknya. Sedangkan bagi Hopkins (dalam Lasse, 2014: 3), pelabuhan diartikan sebagai area tempat kapal dapat melakukan kegiatan pemuatan atau pembongkaran kargo, termasuk dalam area dimaksud suatu lokasi dimana kapal dapat antri menunggu giliran atau tunggu perintah untuk beraktivitas.

\section{Peran dan Fungsi Pelabuhan}

UNCTAD, dalam Lasse, 2014: 5-7 menyebutkan, fungsi pelabuhan adalah: a). Gateway bermakna sebagai pintu gerbang atau gateway. Pelabuhan berfungsi sebagai pintu yang dilalui orang dan barang kedalam maupun keluar pelabuhan yang bersangkutan. b) Link, terdapat tiga unsur penting, fungsi link, yakni: (1) menyalurkan atau memindahkan barang muatan dari kapal ke truk; (2) operasi pemindahan berlangsung secara cepat artinya minimum delay; dan (3) efisien dalam arti biaya. c) Interface, barang muatan yang diangkut via maritim transport setidaknya melintasi area pelabuahan dua kali, yakni satu kali di pelabuhan muat dan satunya kali di pelabuhan bongkar. Di pelabuhan muat dan demikian juga di pelabuhan bongkar dipindahkan dari/ke sarana angkut dengan menggunakan berbagai fasilitas dan peralatan mekanis maupuun non mekanis. Peralatan untuk memindahkan muatan menjembatani kapal dengan truk/kereta api truk/kereta api dengan kapal. Pada kegiatan tersebut fungsi pelabuhan adalah antar muka(interface). d) Industrial entity, pelabuhan yang diselenggarakan secara baik akan bertumbuh dan akan menyuburkan bidang usaha lain sehingga area pelabuhan menjadi zona industri terkait dengan kepelabuhan.

Sedangkan dalam manajemen operasi pelabuhan meliputi hal-hal sebagai berikut:

a. Perencanaan Pelayanan Jasa Kapal

b. Pelaksanaan Operasi Pelayan Kapal

c. Pengendalian Operasi Pelayanan Kapal

d. Pelayanan Jasa Barang

e. Pelayanan Muatan Curah

f. Pelayanan Muatan Ro-Ro 


\section{g. Pelayanan Penumpang}

\section{METODE PENELITIAN}

Penelitian ini menggunakan metode deskriptif jenis kuantitatif, yaitu penelitian deskriptif yang diarahkan untuk menguraikan atau menjelaskan secara rinci apa yang menjadi permasalahan dan tujuan penelitian dengan mengandalkan angka-angka kuantitaif yang kemudian dikualitatifkan. Untuk sampai pada uraian tersebut, digunakan disain penelitian analisis kesenjangan (gap analysis) antara ekspektasi (harapan) perusahaan pelayaran dan kinerja pelayanan transportasi laut Pelabuhan Tanjung Priok.

Unit analisis (populasi) penelitian ini adalah karyawan perusahaan pelayaran yang bertugas mengurus permintaan pelayanan transportasi laut (boarding officer) pada instansi pemerintah (Kantor Imigrasi, Kantor Kesehatan Pelabuhan, Kantor Otoritas Pelabuhan dan Kantor Syahbandar) dan Operator Pelabuhan (PT. Pelabuhan Tanjung Priok) di Pelabuhan Tanjung Priok yang berjumlah 118 orang.

Fokus penelitian ini pada perusahan pelayaran baik ocean going maupun domestik yang meminta pelayanan kapal yang sandar diseluruh terminal pelabuhan Tanjung Priok. Untuk semua kapal, baik kapal rute luar negeri ataupun domestik, baik berjenis kapal general cargo, container, tongkang, tugboat dan penumpang.

Untuk populasi 118, menurut formula Slovin (Umar, 2006: 108) dengan error margin 5\% diperlukan sampel penelitian. Berdasarkan perhitungan tersebut, maka jumlah sampel penelitian ini adalah 91 orang. Pengambilan sampel dilakukan dengan menggunakan teknik simple random sampling, di mana setiap perusahaan pelayaran memiliki peluang yang sama untuk dijadikan sampel penelitian.

\section{HASIL DAN PEMBAHASAN}

\section{Analisis Kualitas Pelayanan}

Hasil perhitungan SERVQUAL Score, yaitu kesenjangan antara harapan dengan kinerja pelayanan transportasi laut pada Pelabuhan Tanjung Priok, Jakarta, dilakukan untuk masing-masing item pernyataan untuk tiap dimensi dengan menggunakan nilai rata-rata. Rincian hasilnya adalah sebagaimana terlihat dalam uraian berikut:

1. Bukti Fisik

Dimensi bukti fisik terdiri dari empat atribut pelayanan, yang terdiri dari: kepemilikan sistem informasi teknologi yang mutakhir untuk proses pelayanan administrasi perijinan kapal (clearance in/out dan pergerakan kapal), kepemilikan sistem informasi teknologi mutakhir untuk proses pelayanan kapal (pergerakan kapal), kepemilikan kapal tunda yang cukup dan bagus untuk pelayanan pergerakan kapal, dan petugas yang handal dan cakap dalam melayani pengguna jasa.

Berikut ini adalah skor yang diperoleh untuk dimensi bukti fisik yang terdiri dari empat atribut pelayanan. 
Tabel 4.1. Skor Servqual Dimensi Bukti Fisik

\begin{tabular}{clccc}
\hline No & \multicolumn{1}{c}{ Atribut } & Harapan & Kinerja & Servqual \\
\hline & $\begin{array}{l}\text { Kepemilikan sistem informasi tegnologi } \\
\text { yang mutakhir untuk proses pelayanan }\end{array}$ & 4,90 & 1,32 & -3.58 \\
$\begin{array}{l}\text { administrasi perijinan kapal ( clearance } \\
\text { in/out dan pergerakan kapal) }\end{array}$ & & & \\
\hline & $\begin{array}{l}\text { Kepemilikan sistem informasi teknologi } \\
\text { mutakhir untuk proses pelayanan kapal } \\
\text { (pergerakan kapal) }\end{array}$ & 5,00 & 3,40 & -1.60 \\
\hline $3 \quad \begin{array}{l}\text { Kepemilikan kapal tunda yang cukup dan } \\
\text { bagus untuk pelayanan pergerakan kapal }\end{array}$ & 4,95 & 3,88 & -1.07 \\
\hline 4 & Tampilan petugas pelabuhan rapi & 4,88 & 3,26 & -1.62 \\
\hline Rata-rata & $\mathbf{4 , 9 3}$ & $\mathbf{2 , 9 6}$ & $\mathbf{- 1 , 9 7}$ \\
\hline
\end{tabular}

Dari tabel di atas secara keseluruhan diperoleh nilai rata-rata sebesar 2,96 untuk skor kinerja pelayanan, 4,93 untuk skor harapan, dan $-1,97$ untuk skor Servqual. Merujuk pada skor-skor ini maka dapat diketahui bahwa dilihat dari dimensi bukti fisik, kinerja pelayanan Pelabuhan Tanjung Priok masih kurang dan berada di bawah harapan perusahaan pelayaran.

2. Keandalan

Dimensi keandalan terdiri dari lima atribut pelayanan, yaitu: ketepatan pelayanan administrasi terkait perijinan operasional kapal sesuai dengan Service Level Agreement, kesesuaian pelayanan sesuai dengan yang telah dijanjikan oleh petugas, pemberian pelayanan oleh petugas sejak awal secara profesional kepada pengguna jasa, pelayanan petugas sesuai dengan waktu yang telah dijanjikan, dan pemberitahuan oleh petugas kapan tepatnya pelayanan akan diberikan. Skor harapan, kinerja dan dan Servqual dari masing-masing atribut dimensi keandalan dapat dilihat pada Tabel 4.2 di bawah ini.

Tabel. 4.2 Skor Servqual Dimensi Keandalan

\begin{tabular}{clccc}
\hline No & \multicolumn{1}{c}{ Atribut } & Harapan & Kinerja & Servqual \\
\hline 1 & $\begin{array}{l}\text { Ketepatan pelayanan administrasi terkait } \\
\text { perijinan operasional kapal sesuai dengan } \\
\text { Service Level Agreement }\end{array}$ & 4,96 & 2,76 & -2.20 \\
\hline 2 & $\begin{array}{l}\text { Kesesuaian pelayanan sesuai dengan } \\
\text { yang telah dijanjikan oleh petugas }\end{array}$ & 4,16 & 2,88 & -1.29 \\
\hline 3 & $\begin{array}{l}\text { Pemberian pelayanan oleh petugas sejak } \\
\text { awal secara profesional kepada pengguna } \\
\text { jasa. }\end{array}$ & 4,74 & 2,88 & -1.86 \\
\hline 4 & $\begin{array}{l}\text { Pelayanan petugas sesuai dengan waktu } \\
\text { yang telah dijanjikan. }\end{array}$ & 4,40 & 2,85 & -1.55 \\
\hline 5 & Pemberitahuan oleh petugas kapan & 3,96 & 2,56 & -1.40 \\
\hline
\end{tabular}


tepatnya pelayanan akan diberikan.

\begin{tabular}{llll}
\hline Rata-rata & 4,44 & 2,76 & $-1,66$ \\
\hline
\end{tabular}

Secara keseluruhan, dari Tabel 4.2 diperoleh skor rata-rata kinerja pelayanan 2,76, skor harapan 4,59, dan skor servqual -1,66. Skor kinerja pelayanan sebesar 2,76 menunjukkan bahwa kantor pelayanan transportasi laut masih cukup baik dalam memberikan pelayanan kepada perusahaan pelayaran dan skor harapan sebesar 4,44 mengindikasikan bahwa perusahaan pelayaran memiliki harapan yang tinggi terhadap keandalan pelayanan pelayanan transportasi laut Pelabuhan Tanjung Priok, Jakarta. Sementara itu skor Servqual sebesar -1,66 memberikan arti bahwa kinerja pelayanan, dalam hal keandalan, masih lebih rendah dari harapan perusahaan pelayaran.

\section{Daya Tanggap}

Dimensi daya tanggap terdiri dari empat atribut pelayanan, yaitu itikad baik petugas di instansi pemerintah untuk memecahkan masalah-masalah perusahaan pelayaran, pemberian pelayanan oleh petugas dengan cepat dan tepat, kesiapsediaan petugas dalam membantu pengguna jasa/perusahaan pelayaran, dan yang ke empat adalah atribut petugas dengan senang hati menerima setiap keluhan pengguna jasa dan segera memberikan solusi. Hasil pengukuran tiap-tiap atribut pelayanan untuk dimensi daya tanggap dapat dilihat pada Tabel 4.3 di bawah ini.

Tabel 4.3 Skor Servqual Dimensi Daya Tanggap

\begin{tabular}{clccc}
\hline No & \multicolumn{1}{c}{ Atribut } & Harapan & Kinerja & Servqual \\
\hline 1 & $\begin{array}{l}\text { Itikad baik petugas di instansi pemerintah } \\
\text { untuk memecahkan masalah-masalah } \\
\text { perusahaan pelayaran }\end{array}$ & 4.21 & 2.89 & -1.32 \\
\hline 2 & $\begin{array}{l}\text { Pemberian pelayanan oleh petugas } \\
\text { dengan cepat dan tepat. }\end{array}$ & 4.89 & 2.76 & -2.13 \\
\hline $3 \quad \begin{array}{l}\text { Kesiapsediaan petugas dalam membantu } \\
\text { pengguna jasa / perusahaan pelayaran }\end{array}$ & 4.68 & 2.63 & -2.05 \\
\hline $\begin{array}{l}\text { Petugas dengan senang hati menerima } \\
\text { setiap keluhan pengguna jasa dan segera } \\
\text { memberikan solusi }\end{array}$ & 4.27 & 2.43 & -1.85 \\
\hline Rata-rata & $\mathbf{4 , 5 1}$ & $\mathbf{2 , 6 8}$ & $\mathbf{- 1 , 8 4}$ \\
\hline
\end{tabular}

Pada tabel di atas terlihat nilai rata-rata dari keempat atribut dimensi daya tanggap sebesar 2,68 untuk kinerja pelayanan, 4,51 untuk skor harapan, dan -1,84 untuk skor Servqual. Skor rata-rata tersebut menggambarkan bahwa secara umum perusahaan pelayaran memiliki harapan yang tinggi terhadap daya tanggap yang baik dalam memberikan pelayanan. Namun demikian perusahaan pelayaran memiliki persepsi bahwa secara umum kinerja Pelabuhan Tanjung Priok belum mampu memenuhi harapannya.

4. Jaminan 
Dimensi jaminan memiliki empat atribut pelayanan, yang meliputi: sikap petugas menanamkan kepercayaan kepada pengguna jasa, rasa aman di lingkungan pelabuhan, kesopanan petugas kepada pengguna jasa, dan pengetahuan yang baik yang dimiliki petugas. Hasil pengukuran tiap-tiap atribut pelayanan untuk dimensi jaminan dapat dilihat pada Tabel 4.4 di bawah ini.

Tabel 4.4 Skor Servqual Dimensi Jaminan

\begin{tabular}{clccc}
\hline No & \multicolumn{1}{c}{ Atribut } & Harapan & Kinerja & Servqual \\
\hline 1 & $\begin{array}{l}\text { Sikap petugas menanamkan kepercayaan } \\
\text { kepada pengguna jasa }\end{array}$ & 4,09 & 2,35 & -1.74 \\
\hline 2 & Rasa aman di lingkungan pelabuhan & 4,30 & 3,79 & -0.51 \\
\hline 3 & Kesopanan petugas kepada pengguna jasa & 3,74 & 3,42 & -0.32 \\
\hline 4 & $\begin{array}{l}\text { Pengetahuan yang baik yang dimiliki } \\
\text { petugas }\end{array}$ & 4,03 & 2,91 & -1.12 \\
\hline Rata-rata & $\mathbf{4 . 0 4}$ & $\mathbf{3 , 1 2}$ & $\mathbf{- 0 , 9 2}$ \\
\hline
\end{tabular}

Dari keempat atribut yang terdapat dalam dimensi jaminan diperoleh skor kinerja pelayanan 3,12, skor harapan 4,04, dan skor Servqual -0,92. Merujuk pada skor-skor ini maka dapat disimpulkan bahwa secara umum perusahaan pelayaran memiliki harapan yang tinggi terhadap dimensi jaminan, namun belum dapat dipenuhi oleh Pelabuhan Tanjung Priok.

5. Empati

Dimensi empati terdiri dari lima atribut pelayanan, yang meliputi: perhatian individual yang diberikan petugas kepada pengguna jasa, jam kerja pelayanan yang fleksibel dan sesuai dengan kebutuhan pengguna jasa, perhatian yang diberikan petugas kepada pengguna jasa secara personal, pemahaman petugas akan minat pengguna jasa, dan pemahaman petugas akan kebutuhan pengguna jasa secara spesifik. Hasil pengukuran tiap-tiap atribut pelayanan untuk dimensi empati dapat dilihat pada Tabel 4.5 berikut.

Tabel 4.5 Skor Servqual Dimensi Empati

\begin{tabular}{clcccc}
\hline No & \multicolumn{1}{c}{ Atribut } & Harapan & Kinerja & Servqual \\
\hline 1 & $\begin{array}{l}\text { Perhatian individual yang diberikan } \\
\text { petugas kepada pengguna jasa. }\end{array}$ & 3,54 & 2,86 & $-0,68$ \\
\hline 2 & $\begin{array}{l}\text { Jam kerja pelayanan yang fleksibel dan } \\
\text { sesuai dengan kebutuhan pengguna jasa }\end{array}$ & 4,90 & 3,74 & -1.16 \\
\hline 3 & $\begin{array}{l}\text { Perhatian yang diberikan petugas kepada } \\
\text { pengguna jasa secara personal. }\end{array}$ & 3,03 & 2,49 & -0.54 \\
\hline 4 & $\begin{array}{l}\text { Pemahaman petugas akan minat } \\
\text { pengguna jasa. }\end{array}$ & 3,74 & 2,70 & -1.03 \\
\hline 5 & $\begin{array}{l}\text { Pemahaman petugas akan kebutuhan } \\
\text { pengguna jasa secara spesifik. }\end{array}$ & 3,47 & 2,71 & -0.76 \\
\hline
\end{tabular}




\begin{tabular}{llll}
\hline Rata-rata & 3,74 & 2,90 & $-0,84$
\end{tabular}

Dari lima atribut pelayanan dimensi empati diperoleh skor rata-rata secara keseluruhan 2,90 untuk kinerja pelayanan, 3,74 untuk skor harapan, dan $-0,84$ untuk skor Servqual. Merujuk pada skor-skor ini dapat disimpulkan bahwa dalam memberikan pelayanan, Pelabuhan Tanjung Priok cukup berempati terhadap perusahaan pelayaran, tetapi empati yang diberikan masih di bawah harapan perusahaan pelayaran.

Dari data-data SERVQUAL Score tiap atribut (item) sebagaimana dijelaskan di atas, maka selanjutnya dapat direkapitulasikan menjadi skor rata-rata tiap dimensi seperti tertera pada Tabel 4.6 berikut.

Tabel 4.6 Rekapitulasi SERVQUAL Score Setiap Dimensi

\begin{tabular}{|c|c|c|c|c|}
\hline No & Dimensi & Harapan & Kinerja & Servqual \\
\hline 1 & Bukti fisik & 4,93 & 2,96 & $-1,97$ \\
\hline 2 & Keandalan & 4,44 & 2,84 & $-1,66$ \\
\hline 3 & Tanggap & 4,51 & 2,68 & $-1,84$ \\
\hline 4 & Jaminan & 4,04 & 3,12 & $-0,92$ \\
\hline 5 & Empati & 3,74 & 2,90 & $-0,84$ \\
\hline \multicolumn{2}{|c|}{ Rata-rata } & 4,33 & 2,90 & $-1,45$ \\
\hline
\end{tabular}

Dari Tabel 4.6 di atas terlihat bahwa Servqual Score dimensi bukti fisik = 1,97 , dimensi keandalan $=-1,66$, dimensi tanggap $=-1,84$, dimensi jaminan $=-$ 1,11 , dan dimensi empati $=-0,84$. Nilai SERVQUAL Score tertinggi adalah dimensi empati $(-0,84)$, sedangkan yang terendah adalah dimensi bukti fisik (1,97). Nilai servqual score tertinggi menunjukkan derajat kesenjangan yang makin besar, atau kinerja pelayanan Pelabuhan Tanjung Priok Jakarta makin tidak sesuai dengan harapan perusahaan pelayaran; sedangkan nilai terendah mengindikasikan tingkat kesenjangan yang makin kecil, atau kinerja pelayanan riil makin sesuai dengan harapan perusahaan pelayaran. Sementara itu nilai rata-rata secara keseluruhan adalah $-1,45$. Hal ini menunjukkan kinerja pelayanan Pelabuhan Tanjung Priok Jakarta secara umum berada di bawah harapan perusahaan pelayaran.

Nilai rekapitulasi skor Servqual di atas juga dapat digambarkan dalam bentuk histogram sebagai berikut: 


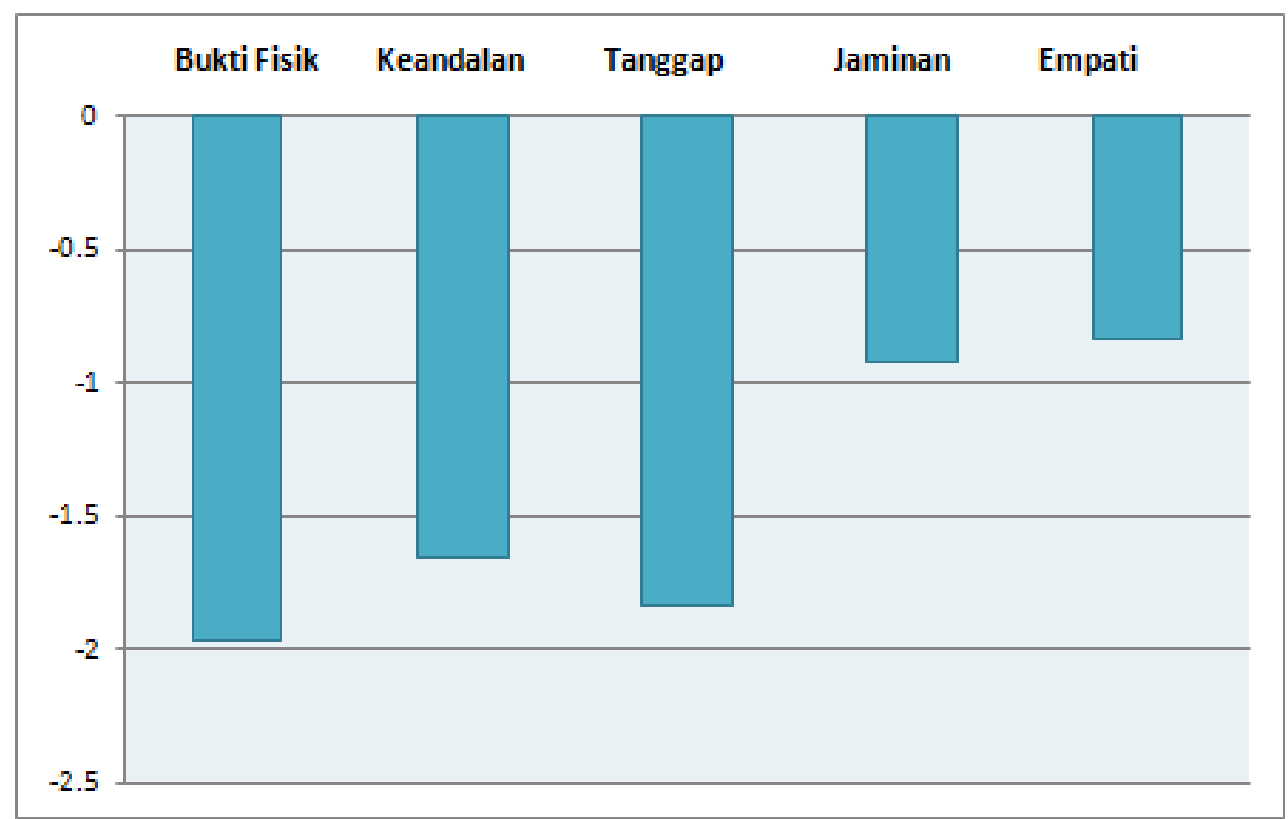

Gambar 4.1 Rekapitulasi Skor Servqual

Pada Masing-masing Dimensi Pelayanan

\section{Analisis Tingkat Kepentingan}

Dalam menilai kualitas pelayanan Pelabuhan Tanjung Priok Jakarta, perusahaan pelayaran mempunyai dimensi-dimensi kualitas pelayanan yang dianggap penting. Analisis tingkat kepentingan perusahaan pelayaran ini berfungsi untuk mengetahui dimensi-dimensi yang menjadi preferensi perusahaan pelayaran, sehingga Pelabuhan Tanjung Priok Jakarta dapat lebih memfokuskan usahanya untuk memenuhi harapan perusahaan pelayaran pada dimensi-dimensi yang dianggap penting. Hasil perhitungan tingkat kepentingan dilihat pada tabel berikut.

Tabel 4.7 Tingkat Kepentingan Perusahaan Pelayaran Terhadap Dimensi-dimensi Pelayanan

\begin{tabular}{clc}
\hline No & \multicolumn{1}{c}{ Dimensi } & $\begin{array}{c}\text { Tingkat } \\
\text { Kepentingan }\end{array}$ \\
\hline 1 & Bukti Fisik & $24,4 \%$ \\
\hline 2 & Keandalan & $24,9 \%$ \\
\hline 3 & Tanggap & $12,0 \%$ \\
\hline 4 & Jaminan & $23,6 \%$ \\
\hline 5 & Empati & $14,9 \%$ \\
\hline
\end{tabular}

Berdasarkan Tabel terlihat bahwa dimensi yang paling mendapat perhatian dan dianggap paling penting oleh perusahaan pelayaran dalam menilai kualitas pelayanan Pelabuhan Tanjung Priok Jakarta adalah dimensi keandalan, yaitu sebesar 24,9\%. Dimensi keandalan meliputi: akurat, ketepatan dan kesesuaian. Kemudian dimensi bukti fisik menempati urutan kedua dengan nilai sebesar 
24,4\%. Dimensi ini mancakup: fasilitas fisik, peralatan dan perlengkapan modern, dan tenaga kerja. Selanjutnya dimensi yang mendapatkan prioritas ketiga adalah dimensi jaminan, dengan nilai sebesar 23,6\%. Dimensi ini meliputi: pengetahuan, kesopanan, menjaga kepercayaan, keamanan dan kenyamanan. Berikutnya adalah dimensi empati yang menempati urutan keempat tingkat kepentingan dengan persentase $14,9 \%$. Dimensi ini meliputi: kepedulian dan perhatian individual. Sementara itu dimensi yang memperoleh prioritas terakhir adalah dimensi daya tanggap (12,0\%). Dimensi ini meliputi: kemauan membantu, layanan segera, kecepatan pelayanan dan menerima keluhan.

Untuk lebih jelasnya mengenai tingkat kepentingan perusahaan pelayaran terhadap dimensi-dimensi pelayanan Pelabuhan Tanjung Priok Jakarta, dapat dilihat pada gambar berikut.

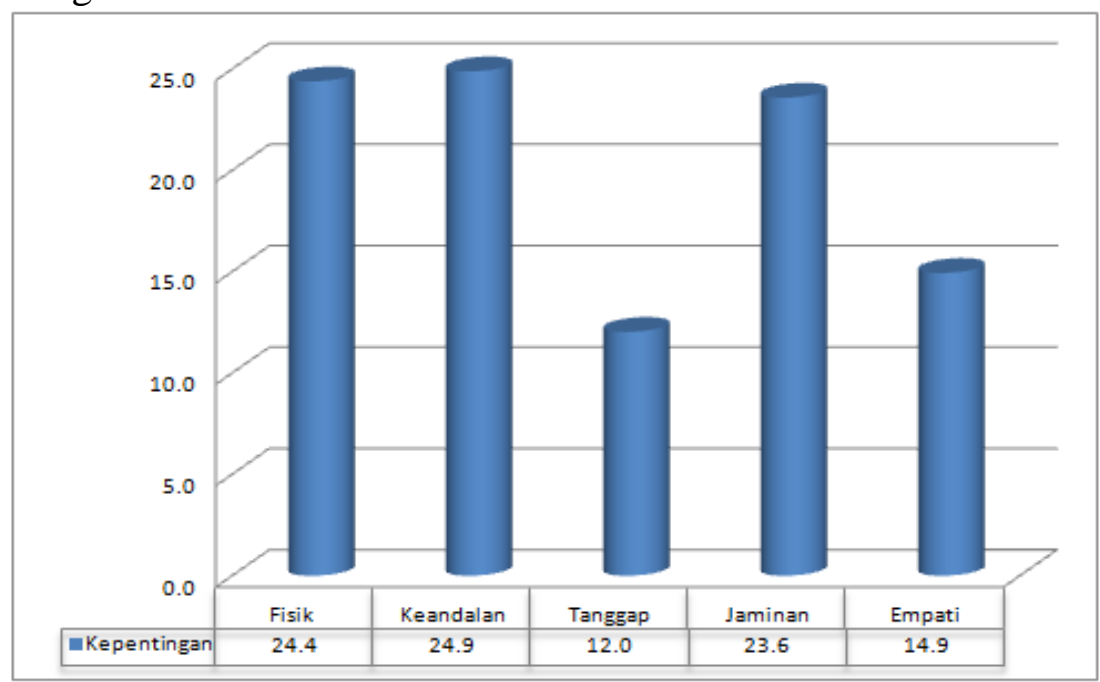

Gambar 4.2 Tingkat Kepentingan Perusahaan Pelayaran

\section{Actual SERVQUAL Score}

Hasil perhitungan actual SERVQUAL Score (skor pelayanan aktual), yakni perbandingan antara skor pelayanan riil yang diperoleh perusahaan pelayaran dengan skor harapan perusahaan pelayaran, dapat dilihat pada Tabel 4.8

Tabel 4.8 Skor Kualitas Pelayanan Aktual Untuk Setiap Dimensi

\begin{tabular}{ccccc}
\hline No & Dimensi & Harapan & Kinerja & $\begin{array}{c}\text { Skor Aktual Kualitas } \\
\text { Pelayanan }\end{array}$ \\
\hline 1 & Bukti Fisik & 4,93 & 2,96 & $60,0 \%$ \\
\hline 2 & Keandalan & 4,44 & 2,78 & $64,0 \%$ \\
\hline 3 & Daya Tanggap & 4,59 & 2,76 & $59,4 \%$ \\
\hline 4 & Jaminan & 4,09 & 2,98 & $77,2 \%$ \\
\hline 5 & Empati & 3,74 & 2,90 & $77,5 \%$ \\
\hline & Rata-rata & $\mathbf{4 , 3 3}$ & $\mathbf{2 , 9 0}$ & $\mathbf{6 7 , 0 \%}$ \\
\hline
\end{tabular}

Berdasarkan hasil perhitungan actual Servqual Score di atas terlihat bahwa skor tertinggi menunjuk pada dimensi empati (77,5\%). Ini menunjukkan bahwa 
pemenuhan harapan perusahaan pelayaran pada dimensi empati lebih baik dibandingkan keempat dimensi lainnya. Dimensi selanjutnya yang mendapatkan pemenuhan lebih baik secara berturut-turut adalah dimensi jaminan (77,2\%), keandalan $(64,0 \%)$, bukti fisik $(60,0 \%)$, dan daya tanggap $(59,4 \%)$. Sementara itu, secara keseluruhan harapan perusahaan pelayaran dari lima dimensi terpenuhi 67,0\%. Ini berarti masih terdapat 33,0\% harapan perusahaan pelayaran terhadap layanan transportasi laut Pelabuhan Tanjung Priok Jakarta yang belum terpenuhi.

\section{Weighted SERVQUAL Score (WSC)}

Hasil perhitungan WSC (skor SERVQUAL dengan pembobotan), yakni perkalian skor kualitas pelayanan dengan skor tingkat kepentingan perusahaan pelayaran masing-masing dimensi terpapar dalam Tabel 4.9. Perlu diketahui bahwa WSC digunakan untuk mengetahui prioritas perbaikan pada masingmasing dimensi pelayanan.

Tabel 4.9 Perhitungan Skor SERVQUAL Dengan Pembobotan

\begin{tabular}{ccccc}
\hline No & Dimensi & $\begin{array}{c}\text { Skor } \\
\text { SERVQUAL }\end{array}$ & $\begin{array}{c}\text { Skor Tingkat } \\
\text { Kepentingan }\end{array}$ & WSC \\
\hline 1 & Bukti fisik & $-1,97$ & 0,244 & $-0,480$ \\
\hline 2 & Keandalan & $-1,66$ & 0,249 & $-0,413$ \\
\hline 3 & Daya Tanggap & $-1,84$ & 0,120 & $-0,220$ \\
\hline 4 & Jaminan & $-0,92$ & 0,236 & $-0,217$ \\
\hline 5 & Empati & $-0,84$ & 0,149 & $-0,125$ \\
\hline$\quad$ Rata-rata & & & $\mathbf{- 0 , 2 9 1}$ \\
\hline
\end{tabular}

Dari perhitungan WSC sebagaimana terlihat pada Tabel 4.9, kelima dimensi kualitas pelayanan memperoleh nilai negatif. Hal ini menunjukkan bahwa kinerja kelima dimensi tersebut belum memenuhi harapan perusahaan pelayaran, sehingga pihak Pelabuhan Tanjung Priok Jakarta sebaiknya melakukan tindakan perbaikan terhadap kelima dimensi sesuai dengan urutan prioritasnya. Urutan prioritas perbaikan tersebut dapat mengacu pada nilai WSC dari terbesar sampai yang terkecil, yakni: bukti fisik $(-0,480)$, keandalan $(-0,413)$, daya tanggap ($0,220)$, jaminan $(-0,217)$, dan empati $(-0,125)$. 


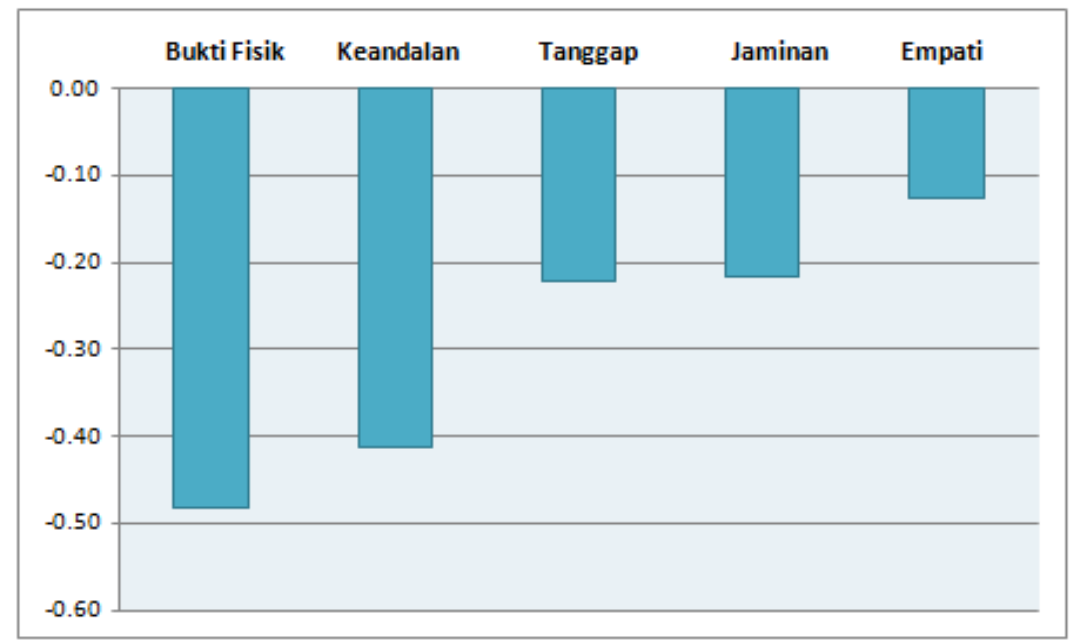

Gambar 4.3

\section{SIMPULAN}

Prioritas Perbaikan Dimensi Pelayanan

Berdasarkan analisis hasil penelitian yang telah dipaparkan, kesimpulan penelitian ini adalah: 1) Secara umum kinerja pelayanan Pelabuhan Tanjung Priok Jakarta dinilai oleh perusahaan pelayaran cukup baik dengan skor rata-rata tingkat kinerja sebesar 2,90. 2) Tingkat harapan pelayanan perusahaan pelayaran di Pelabuhan Tanjung Priok Jakarta tergolong tinggi dengan skor rata-rata tingkat harapan sebesar 4,33. 3) Dimensi pelayanan di Pelabuhan Tanjung Priok Jakarta yang dianggap paling penting adalah keandalan, yang meliputi: akurat, ketepatan dan kesesuaian. Urutan selanjutnya adalah dimensi fisik, daya tanggap, jaminan dan empati. 4) Masih terdapat kesenjangan (gap) antara kinerja dengan harapan pelayanan, sehingga menunjukkan bahwa Pelabuhan Tanjung Priok Jakarta belum dapat memenuhi harapan perusahaan pelayaran. Tingkat pemenuhan harapan pelayanan transportasi laut pada Pelabuhan Tanjun Priok hanya sebesar 66,9\%.

\section{DAFTAR PUSTAKA}

Albari, (2009). "Pengaruh Kualitas Jasa Perguruan Tinggi Swasta terhadap Loyalitas Mahasiswa," Jurnal Siasat Bisnis Vol. 13 No. 3

Alma, Buchari, (2013). Manajemen Pemasaran dan Pemasaran Jasa. Bandung: Penerbit Alfa Beta.

Faisal, Sanafiah, (2003). Format-format Penelitian Sosial, Jakarta: PT RajaGrafindo Persada

Fitzsimmons, James A. and Monal J. Fitzsimmons, (2006). Service Management: Operations, Strategy, Information Technology, New York: McGraw-Hill,

Ganguli, Shirshendu and Sanjit Kumar Roy, "Service quality dimensions of hybrid services," Managing Service Quality Vol. 20 No. 5, 2010, 404-424

Gaspersz, Vincent, (2002). Total Quality Management (TQM), Jakarta: PT Gramedia Pustaka Utama,

Jasfar, Farida, (2009). Manajemen Jasa: Pendekatan Terpadu. Jakarta: Penerbit Ghalia Indonesia 
Kandampully, Jay, (2011). Service Management: The New Paradigm Retailing. New York: Springer Science Business Media

Kartajaya, Hermawan, (2009).Service Operation. Jakarta: Penerbit ESENSI

Lasse, D. A., (2014). Manajemen Kepelabuhanan, Jakarta: PT Rajagrafindo Persada,.

, (2014). Manajemen Bisnis Transportasi Laut Carter dan Klaim, Jakarta: Nika,

Kotler, M., (2003). Marketing Management, International Edition, New Jersey: Prentice Hall,

Lovelock, Christopher and Jochen Wirtz, (2007). Sevices Marketing: People, Technology, Strategy, USA: Prentice Hall

Lupiyoadi, Rambat, (2001). Manajemen Pemasaran Jasa, Teori dan Praktik, Jakarta: Salemba Empat

Majid, Suharto Abdul, (2011). Customer Service Dalam Bisnis Jasa Transportasi, Jakarta: Penerbit Rajawali Press

Moenir, (2006). Manajemen Pelayanan Umum di Indonesia. Jakarta: PT. Bumi Aksara,.

Ratminto dan Atik Winarsih, (2005). Manajemen Pelayanan. Yogyakarta: Pustaka Pelajar

Setiawan, Supriadi, (2011). Loyalitas Pelanggan Jasa: Studi Kasus Bagaimana Rumah Sakit Mengelola Loyalitas Pelanggannya. Bogor: Penerbit IPB Press,

Setyawan, Henry, (2012). Kualitas Pelayanan Trasnportasi, Jakarta: Penerbit Fakultas Ekonomi, Universitas Indonesia

Shahin, Arash, (2007).SERVQUAL and Model of Service Quality Gaps: A Framework for Determining and Prioritizing Critical Factors in Delivering Quality Services, http://www.qmconf.com/ Docs/0077.pdf

Simamora, Bilson, (2003). Memenangkan Pasar Dengan Pemasaran Efektif dan Profitabel. Jakarta: Gramedia Pustaka Utama

Supranto, J., (2006). Pengukuran Tingkat Kepuasah Pelanggan: Untuk Menaikkan Pangsa Pasar, Jakarta: Rineka Cipta

Sutrisno, Hadi, (2003). Metodologi Research 2, Yogyakarta: Yayasan Penerbitan Fakultas Psikologi Universitas Gajah Mada

Tjiptono, Fandy, (2004). Manajemen Jasa, Yogyakarta: Andi , (2014). Pemasaran Jasa: Prinsip, Penerapan, Penelitian. Yogyakarta: Andi Offset,

Tjiptono, Fandy dan Anastasia Diana, (2001). TQM: Total Quality Management, Yogyakarta: Andi

Tjiptono, Fandy dan Gregorius Chandra, (2011). Service, Quality dan Satisfaction, Edisi Tiga. Yogyakarta: Penerbit Andi Offset

Undang-Undang R.I. Nomor: 25 Tahun 2001 tentang Pelayanan Publik, Jakarta: Indonesia.go.id

Winkler, Deborah, (2009). Services Offshoring and its Impact on the Labor Market: Theoretical Insights, Empirical Evidence, and Economic Policy Recommendations for Germay. New York: Physica Verlag Berlin Heidelberg 
Zeithaml, V.A., Parasuraman, A., and Berry, L.L. (1990)., Delivering Quality Service: Balancing Customer Perseptions and Ecpectations, New York: The Free Press

Zeithaml, Valarie A. dan Mary Jo Bitner. (2009). Service Marketing: Integrating Customer Focus Across the Firm. New York: McGraw-Hill. 